RESEARCHS / INVESTIGACIÓN

\title{
Morphotaxonomy and Distribution of Marine Green Algal Flora in Kalegauk Island
}

Thet Htwe Aung

DOI. 10.21931/RB/2019.04.01.6

\begin{abstract}
The marine green algae were collected from Apor Seik, Pashyu Chaung, Chaytoryar Pagoda, Alè Seik, Auk Sei, and Kyunn Pyet or Cavendish Island along the Kalegauk Island from September 2016 to January 2017. In the study areas, salinity range and temperature regimes seawater were $26-27 \%$ and $29^{\circ} \mathrm{C}$ to $31^{\circ} \mathrm{C}$, respectively. Mainly the present study had been made to know the diversity and distribution of marine green algae along the Kalegauk Island. Marine green algae were identified based on their internal and external morphological characters. The total 14 species could be recorded in Kalegauk Island. Of these species, almost all species were first new records for Kalegauk Island.Alson, it was concluded that all species would be the most diverse and abundant in Apor seik. Moreover, the present study could provide evaluating the impacts of marine green algae resources caused by infrastructures in the future.
\end{abstract}

Keywords: Morphological characters, Kalegauk, New record, and green algae.

\section{Introduction}

Marine benthic green algae are usually found in the intertidal zone and in shallow waters where there are plenty of nutrients and sunlight. Green algae usually appear in green because they contain the same ratio of chlorophyll $a$ and $b$ as that of higher plants. Hence, it is generally believed that green algae are closely related to terrestrial higher plants in the theory of biological evolution ${ }^{1}$

Kalegauk Island is the island in Ye township, Mon state, Myanmar. It is located in the northern part of the Andaman Sea, $8.25 \mathrm{~km}$ from the coast of Mon. The island has a long shape with a length of over $10 \mathrm{~km}$ and a width of $1.6 \mathrm{~km}$ in itsmost extensivet are, and there is a small Cavendish island lies 0.5 $\mathrm{km}$ off thesouthernn point of Kalegauk Island. It is mainly composed of four villages, viz., Apor Seik Village, Auk Seik Village, Alè Seik Village and Pashyu Chaung VillageAlsoon, Chaytoryar Pagoda is also one of the most famous places in Kalegauk IslandMangrove forests rather than rocky shores generally cover the coastal areas of the Kalegauk Islandes. The coastlines of Kalegauk Island dominantly comprise ocovereder by mud, silt and clay and many capes or promontories on these areas. In the study areas, salinity range and temperature regimes seawater were $26-27 \%$ and $29^{\circ} \mathrm{C}$ to $31^{\circ} \mathrm{C}$, respectivelyNowadaysay Kalegauk Island has been declared as the island to be constructed deep sea port.

Therefore, thprimaryin objective of the present study is to record the diversity and distribution of marine benthic green algae from Kalegauk Island with their morphological characters. As a result, this study will become primaryic informational providing data for further observing on the marine green algae of Kalegauk Island.

\section{Materials and methods}

Marine green algae were collected in the forms of drift and live specimens growing in the high tide line, intertidal and shallow subtidal areas from Apor Seik, Pashyu Chaung, Chaytoryar Pagoda, Alè Seik, Auk Seik and Kyunn Pyet from September 2016 to January 2017. The site location, topography, associated flora and fauna and other related parameters of Kalegauk Island were recorded. In the field, all the adhering materials such as sand particles and other debris as well as epiphytes were removed from the samples with the help of painting brush before preservation. The seaweed samples preserved $4 \%$ formaldehyde with seawater. All the bags and containers were labeled withe th date, time of collection, locality and transport to the laboratory of Marine Science Department for further analysis.

In the laboratory, color and morphological differences between different genus, species and taxonomic characters firstly studied and then the collected seaweeds had been identified wian th emphasis on the external and internal morphologies of vegetative and reproductive features. For internal details studies of the thallcross-sectionion (c.s) were obtained freehandand with shaving blades, then stained in Aniline Blue (0.5 $\mathrm{g}$ water soluble aniline blue in $100 \mathrm{ml}$ distilled water and 5 $\mathrm{ml}$ conc. Acetic acid) and mounted in glycerine. Vegetative and reproductive structures of the plants were studied under the Olympus compound microscope and Kaneko Yushima dissecting microscope. Microscopic measurements were recorded in micrometer $(\mu \mathrm{m})$ using the ocular meter. This stuly followed the classification system of Guiry and Guiry? 


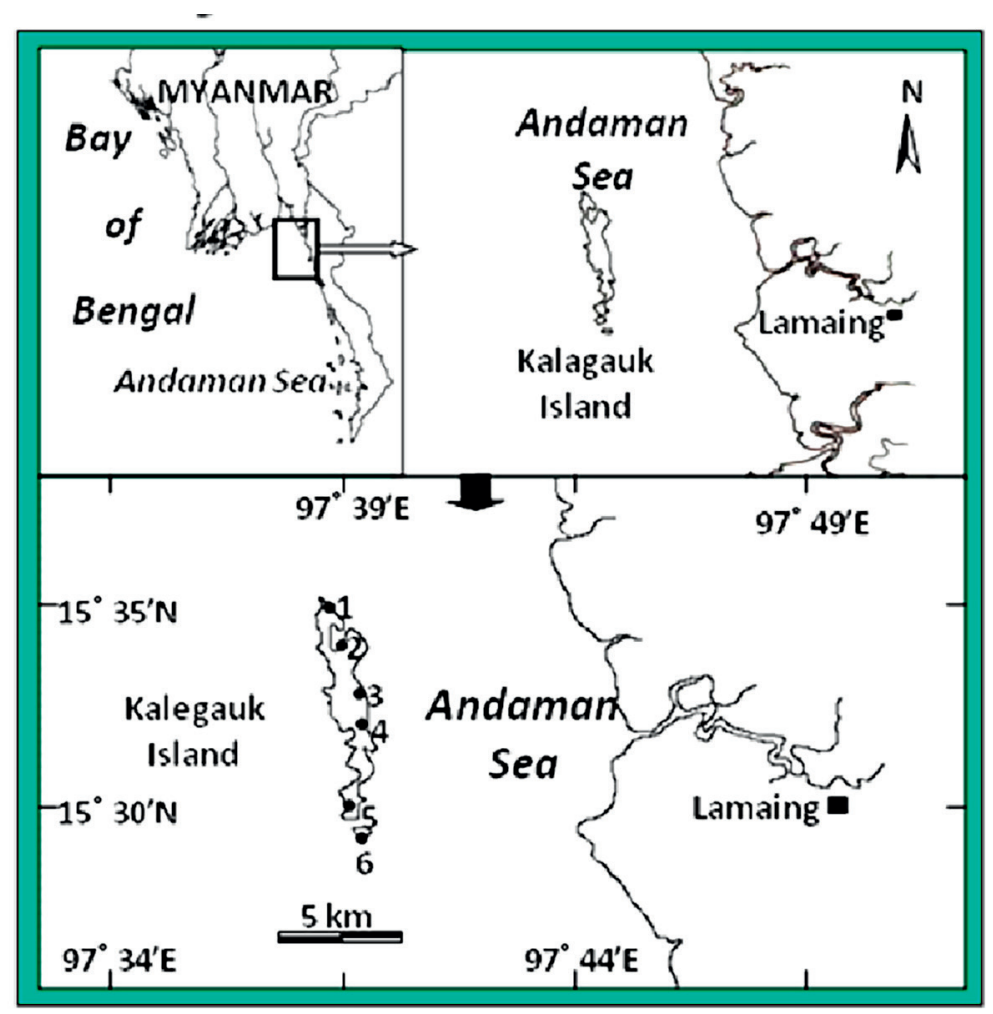

Fig 1. Map showing the specimens collection sites of the marine benthic algae of Kalegauk Island in the northern part of the Andaman Sea. 1. Apor Seik. 2. Pashyu Chaung. 3. Chaytoryar Pagoda. 4. Alè Seik. 5. Auk Seik. 6. Kyunn Pyet or Cavendish Island.

\section{Results}

\section{Descriptions of marbenthicntic green algae (Chloro- phyta) in Kalegauk Island}

\section{Key to the species of Ulva from Kalegauk Island}

1a. Thalli tubular, the blade tapering to the base Ulva compressa

1b. Thalli unbranched, the blade linear to broad U. linza

\section{Ulva compressa Linnaeus (figs. 2-6)}

Ulva compressa Linnaeus 1753: 1633. Taxonomic synonyms: Enteromorpha compressa (Linnaeus) J. Agardh: Martens 1871: 4654; Anand 1940: 11, fig.1A5; Dawson 1944: 2036; Kylin 1949: 22-237; Yamada 1950: 1738; Durairatnam 1961:18, pl.I, fig. $7^{9}$; Soe-Htun 1998: 10410; Soe Pa Pa Kyaw et al. 2009: 44-45, fig.5ㄹ; Soe-Htun et al. 2009: 27012; Jha et al. 2009: 8, fig. A-C ${ }^{13}$; Pham et al.2011: 5214; Guiry and Guiry $2018^{2}$.

Description. Thalli tubular, gregarious, more or less compressed, dilated towards the apex, tapering to the base, to $1-3 \mathrm{~cm}$ tall, greenish yeolor. Profusely branched but the branches ooccasionallyally branched, branches narrowed to base, similar to centralmfrontrond, often with hollow margins. In surface view cells irregularly arranged, polygonal, 12-16 $\mu \mathrm{m}$ long and 12-20 $\mu \mathrm{m}$ wide. In transverseerse section cells irregularly rounded, 16-20 $\mu \mathrm{m}$ long and 12-16 $\mu \mathrm{m}$ wide. In the upper portion, cells 8-12 $\mu \mathrm{m}$ long and 4-8 $\mu \mathrm{m}$ wide.

Distribution. Apor Seik, Pashyu Chaung, Chaytoryar Pagoda, Alè Seik, Auk Seik, Kyunn Pyet.

\section{Ulva linza Linnaeus (figs. 7-9)}

Ulva Linza Linnaeus 1753: 163³. Taxonomic synonyms: Enteromorpha linza (Linnaeus) J. Agardh: Kylin 1949: 19-20; ;omersley 1956: 3531; Arasaki 1964: 8, fig. 18A-B15; Taylor 1967:

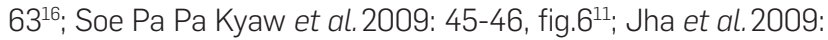
11, fig. A-C ${ }^{13}$; Soe-Htun et al.2009: 27A ${ }^{12}$, Guiry and Guiry $2018^{2}$.

Description. $T$ arehalli unbranched, silky, often gregarious, up to $2-5 \mathrm{~cm}$ tall, yellowish green in color. The blade linear to broad, usually with crisped or ruffled margins and at times spirally twisted, blade alentirelyetely compressed apart from a narrow marginal cavity with the two layers separated by mucilage and moderately adherThe marginargin of blades frequehallowsallow because of separation of the two cell layer. In surface view, cells arranged irregularly, 8-16 $\mu \mathrm{m}$ in diametercross-sectionction cit is usually elongatedgated, two rows, 8-16 $\mu \mathrm{m}$ long and 6-15 $\mu \mathrm{m}$ wide. In the upper portion, cells 8-12 $\mu \mathrm{m}$ and 8-1full wide.

Distribution. Apor Seik, Pashyu Chaung, Chaytoryar Pagoda, Alè Seik, Auk Seik, Kyunn Pyet.

\section{Key to the species of Cladophora from Kalegauk Island}

1a. Branches profuse, in curved near the tips and common pseudodichotomous branches Cladophora vagabunda

1b. Branches sparse, not in curved near the tips and rare pseudodichotomous branches Cladophorasp.

Cladophora vagabunda (Linnaeus) Hoek (figs. 10-11)

Cladophora vagabunda (Linnaeus): Anand 1940: 28-29, figs. 12A-B ${ }^{5}$; Womersley 1956: 3581; Durairatnam 1961: 21-22, pl II, fig.19; Guiry and Guiry $2018^{2}$. 
Description. Thalli of uniseriate branched filaments with apical and intercalary growth, up to $3.5 \mathrm{~cm}$ tall, light green in color, composed of pseudodichotomously brancentralg main axis ending in densely branched fasciculate terminal branch systems. In main branches, cells cylindrical, 875-1000 $\mu \mathrm{m}$ long and 75-100 $\mu \mathrm{m}$ widsecondaryundary branches, cells 375$625 \mu \mathrm{m}$ and 50-75 $\mu \mathrm{m}$ wide. Branchlets pectinately arranged and the tip are cells tapering.

Distribution. - Apor Seik and Alè Seik.

\section{Cladophora sp. (figs. 12-14)}

Description. Thalli, uniseriate branched filaments with apical and intercalary growth, green to duln color, entathick, bushy, slender-celled filaments contorted, repeatedly dichotomous branch, grow in rock pools in the intertidal zone. Main axis stout, alternately branched, 180-150 $\mu \mathrm{m}$ long and 50-100 $\mu \mathrm{m}$ wide. Branches are sparse and rare pseudodichotomous branches. In lateral branches, the tip cells tapering, 100-110 $\mu \mathrm{m}$ long and $40-70 \mu \mathrm{m}$ wide.

Distribution. Apor Seik and Alè Seik.

\section{Chaetomorpha spiralis Okamura (figs. 15-16)}

Chaetomorpha spiralis Okamura 1903: 131-13217; Arasaki 1964:10: fig.2515; Abbott and Hollenberg 1976: 101-10318; Kyaw Soe and Kyi Win 1977: 56, figs.73A1-219; Guiry and Guiry $2018^{2}$.

Description. Plants uniseriate, unbranched, erect, gregarious, dark green in color, rigid, much coiled and contorted when young, later loosened and entangled among other algae, short, slender, and attached to the substra atum by discoidal holdfast. Discoidal holdfasts are 300-400 $\mu \mathrm{m}$ long and 30-150 $\mu \mathrm{m}$ wide. Cells are moniliform to nearly cylindrical, 225-625 $\mu \mathrm{m}$ long and 155-250 $\mu \mathrm{m}$ wide. The length of the cells usually about 2-3 times the diameter. Seik.

Distribution. Apor Seik, Pashyu Chaung, Alè Seik and Auk

\section{Chaetomorpha aerea (Dillwyn) Kützing (figs. 17-21)}

Chaetomorpha aerea (Dillwyn) Kützing: Dawson 1944 2086; Kylin 1949: 48, fig. 507; Womersley 1956: 3551; Durairatnam1961: 20, pl. 1, fig.109; Taylor 1967: 7216; Kyaw Soe and Kyi Win 1977: 55, fig. 74A1-219; Guiry and Guiry $2018^{2}$.

Description. - Plants are erect, uniseriate, unbranched, rigid, gregarious, dark green in color, slender toward the base and attached by a basal cell which is below. Cells swell one times after two or three cells, little contracted at the septa, 50-200 $\mu \mathrm{m}$ long and 50-80 $\mu \mathrm{m}$ thick. A basal cell is longer than other cells.

Distribution. Apor Seik and Pashyu Chaung.

\section{Chaetomorpha gracilis Kützing (figs. 22-25)}

Chaetomorpha gracilis Kützing: Durairatnam 1961: 199; Kyaw Soe and Kyi Win 1977: 56, fig. 74A ${ }^{19}$; Phang 2006: 11820; Soe-Htun et al.2009: 271'2; Soe Pa Pa Kyaw et al.2009: 52, fig. 1711; Pham et al. 2011: 1314, Guiry and Guiry $2018^{2}$.

Description. - Plants uniseriate, unbranched, erect, cylindrical, green to dark green in color, entangled among other algae, grow in tufts, attached to the substratum by irregularly ramified rhizoids, gregarious. Cells little contracted at the septa, $600-750 \mu \mathrm{m}$ long and 200-225 $\mu \mathrm{m}$ wide. The length of the cells usually about 2-4 times than the diameter.
Distribution. Apor Seik, Pashyu Chaung, Alè Seik and Auk Seik.

\section{Chaetomorpha linum (Müller) Kützing (figs. 26-28)}

Chaetomorpha linum (O.F. Müller) Kützing: Kylin 1949: 497; Yamada 1950: 1778; Dawson 1956: 78, fig.1006; Womersley 1956: 357'; Soe-Htun et al. 2009: 27012; Soe Pa Pa Kyaw et al. 2009: 51, fig.16"1; Guiry and Guiry $2018^{2}$.

Description. Plants uniseriate, unbranched, erect, gregarious, grass-green to yellowish-green in color, loosely entangled, stiff. Filaments are often very long, tapering toward the base and curved toward the back at the top. Cells slightly contracted at the septa, subclavate, 50-100 $\mu \mathrm{m}$ long and $50-90 \mu \mathrm{m}$ wide. The length of the cells usually $1-2$ times the diameter. Seik.

Distribution. Apor Seik, Pashyu Chaung, Alè Seik and Auk

\section{Rhizoclonium curvatum Chapman (figs. 29-34)}

Rhizoclonium curvatum V.J Chapman 1949: 49622; Womersley 1984: 170, figs. 53E-F²; Guiry and Guiry $2018^{2}$.

Description. Plants forming mats, dark green in color, entangled with each other, commonly bent and laterally attached with branchlets. Branchlets 250-300 $\mu \mathrm{m}$ long and 20-30 $\mu \mathrm{m}$ wide, septate, erect and segmented. Cells are stout, $30-40 \mu \mathrm{m}$ long and 20-30 $\mu \mathrm{m}$ wide.

Distribution. Apor Seik, Pashyu Chaung and Alè Seik.

\section{Rhizoclonium riparium (Roth) Harvey (figs. 35-37)}

Rhizoclonium riparium (Roth) Harvey: Kylin 1949: 507; Womersley 1956: 361'; Durairatnam 1961:199; Taylor 1967: 76 ${ }^{16}$; Kyaw Soe and Kyi Win 1977: 58, fig.79,pl.1-219; Soe Pa Pa Kyaw et al. 2009: 53, fig.18-1911; Soe-Htun et al. 2009: 271'2; Guiry and Guiry 2018?2.

Description. Plants small, along unbranched filaments, dark green to yellowish-green in color, straight to irregularly curved, sometimes twisted and entangled in thin mats or strands. Cells are cylindrical, 12-28 $\mu \mathrm{m}$ long and 8-12 $\mu \mathrm{m}$ wide. Cells are usually 2-3 times longer than broad. Rhizoids are irregular in position and rare or nonseptate.

Distribution. Apor Seik, Pashyu Chaung, Alè Seik and Kyunn Pyet.

\section{Rhizoclonium grande Boergesen (figs. 38-41)}

Rhizoclonium grande Boergesen: Yoshida, Nakajima and Nakata 1985: 60; 1990: 27223; Abbott and Huisma 2004: 82, fig. 25B ${ }^{24}$, Soe-Htun et al. 2009: 271'2; Guiry and Guiry $2018^{2}$.

Description. Plants in dsmallmats or short stands, dyellow-green yellow green in color, entangled with each other, stiff and irregularly curved. Rhizoidal branches many, long, twisted, septate or nonseptate and tapering toward the tip. Cells elongated, 50-120 $\mu \mathrm{m}$ long and 40-60 $\mu \mathrm{m}$ wide.

Distribution. Apor Seik, Pashyu Chaung, Alè Seik, and Kyunn Pyet.

\section{Rhizoclonium africanum Kützing (figs. 42-45)}

Rhizoclonium africanum Kützing: Lawson and Price 1968: 32925; Abbott and Huisman 2004: 82, fig. 25A24; Soe-Htun et al. 2009: 271'12; Guiry and Guiry $2018^{2}$.

Description. Plants filamentous, tending to be stiff or coarse and pale to dark green in color. Cells are 140-160 $\mu \mathrm{m}$ 
long and 35-40 $\mu \mathrm{m}$ wide, 2-4 times longer than wide. Rhizoidal branches few to many, short and septate.

Distribution. Apor Seik, Pashyu Chaung, and Alè Seik.

\section{Cladophoropsis membranaceae (Hofman Bang ex C. Agardh) Boergesen (figs. 46-48)}

Cladophoropsis membranaceae (Hofman Bang ex C Agardh) Boergesen: Anand 1940: 47-48, figs.25-265; Egerod 1952; 356, fig. $3^{26}$, Dawson 1956: 80, fig.1036; Taylor 1967: 117, pl.2, fig.1, pl.3, fig.216; Soe-Htun et al. 2009: 271'12, Guiry and Guiry $2018^{2}$.

Description. Plants forming tuft or clump of branched filaments, gloomy, light green in color, up to $4.5 \mathrm{~cm}$ long or broad. Most of the filaments declined, twisted and contorted forming entangled masses. Branches are sparse, usually secund, irregular, and without septa. In main axis, segments 300 $800 \mu \mathrm{m}$ long and 100-120 $\mu \mathrm{m}$ wide. Branches are 300-600 $\mu \mathrm{m}$ long and 80-100 $\mu \mathrm{m}$ wide.

Distribution. Apor Seik, Pashyu Chaung, Chaytoryar Pagoda, Alè Seik, Auk Seik, Kyunn Pyet.

\section{Dichotomosiphon sp. (figs. 49-52)}

Description. Plants small, composed of siphonous tubes with constriction at points of ditrichotomous branching, pale green in color and not segmented. Branches network in shape, rounded at the tip, 80-40 $\mu \mathrm{m}$ long and 12-20 $\mu \mathrm{m}$ wide.

Distribution. Apor Seik and Chaytoryar Pagoda.

\section{Discussion}

Tin Aung Myint. ${ }^{27}$ was firstly observed the eeds around the Kalegauk Island in 1971. After that, some marine algae of Kalegauk Island had been described as a small part of their algal flora study in Myanmar by Kyaw Soe and Kyi Win in $1977^{19}$. Since 1977, there was no record and study about the marine algae in Kalegauk Island. Compared with the present study in which the total 12 species of green algal flora could be recorded, almost all species were new records for the seaweed resources of Kalegauk Island with the exception of Rhizoclonium ripariumand Dichotomosiphon sp. which had been described in the previous studies. Therefore, it could be possible that the present study was the first specific record for the marine green algal flora of Kalegauk Island.

Compared with the previous studies of green algal flora in Myanmar, Rhizoclonia um curvatum was new record for Myanmar in the present study according to the references available. However, Cladophora sp. and Dichotomosiphonsp. could not be identified up to the species level due to lack of specimens and references.

Chaetomorpha spiralis, C. aerea and Dichotomosiphon sp. had not been recorded in distribution and potential utilization of marine algae of Myanmar by Soe Htun et al. 200912. However, these species were reported in seaweed for utilization by Kyaw soe and Kyi Win $1977^{19}$. It is well-known that Kalegauk Island can be one of the islands without depleting its algae resources compared to the other areas of Myanmar.

As regards the distinguishing morphological characters, the filaments of Rhizoclonium curvatum were laterally attached with segmented branchlets or celled rhizoids at their curves whereas those of other Rhizoclonium only had rhizoidal branchlets. Likewise, Chapman $1949^{22}$ also described this species seems fosharpight to distinct curves sepacalledby fairly celled rhizoids, forming position $Y$ at the junction. The present ady was found the similar result. Moreover, it was strange that Dichotomosiphon sp was only one the species which is composed of siphonous tubes with constriction at points of ditrichotomous branching.

During the field study, Ulva compressa, $U$. Linza and $\mathrm{Cl}$ adophoropsis membranaceae were ubiquitous and were found everywhere in Kalegauk Island. Cladophora vagabun$d a$ and Cladophora sp. were commonly found in the mangrove forests of Apor Seik and Alè Seik. Chaetomorpha gracilis, C. linum and $C$. spiralis were too numerous in the rocky shore as well as mangrove forests of Apor Seik, Auk Seik, Alè Seik and Pashyu Chaung. Chaetomorpha aereawere found in Apor Seik and Pashyu Chaung. Rhizoclonium riparium, $R$. grande, $R$. africanum and $R$. curvatum were also scattered in the rocky shore and mangrove forest of Apor Seik, Alè Seik and Pashyu Chaung. Dichotomosiphonsp grows on silt and mud of Apor Seik and Chaytoryar Pagoda and then it was too smaquicklycoAlsoeasily. In addition, the green algal flora species were found 14 numbers of species in Apor Seik, 11 numbers of species in Pashyu Chaung, 4 numbers of species in Chaytoryar Pagoda, 12 numbers of species in Chaytoryar Pagoda, 6 numbers of species in Auk Seik and 3 numbers of species in Kyunn Pyet.

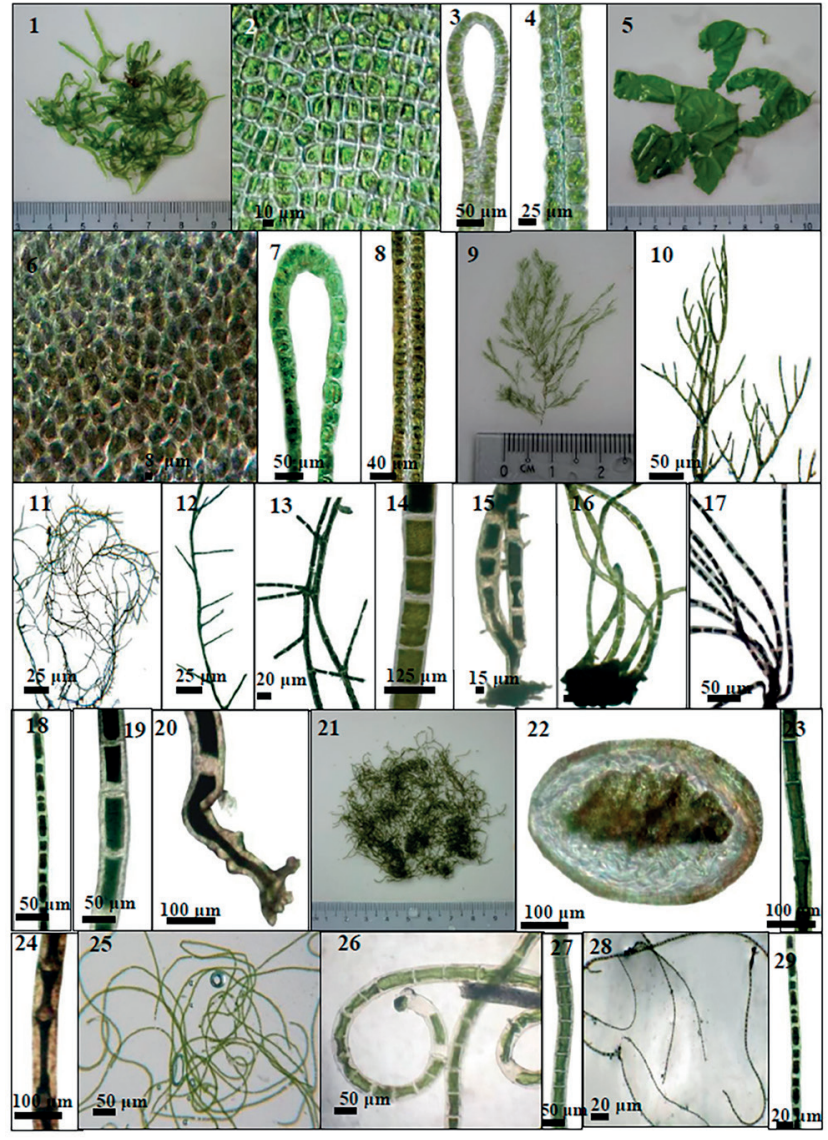

Figs. 2. Habit of Ulva compressa; 3) Surface view; 4) Cross section of older thallus margin.; 5) Cross section of the upper part of a blade; 6) Habit of Ulva linza; 7) Surface view; 8) Cross section of older thallus margin; 9) Cross section of the upper part of a blade; 10) Habit of Cladophora vagabunda; 11) Upper branch system; 12) Habit of Cladophora sp; 13-14) Branch system; 15) Middle part ofChaetomorpha spiralis; 16) Discoid Holdfast; 17) Discoid holdfast of C. aerea; 18) Habit of C. aerea; 19) Middle part; 20) Lower cells; 21) Base of filaments: 22) Habit of Chaetomorpha gracilis; 23) Cross section; 24) Uppermost cells of filaments; 25) Lower cells of filaments;; 26) Habit of Chaetomorpha linum; 27) Part of a coiled filament; 28) Middle part: 29) Habit of Rhizoclonium curvatum; 30 ) Cells of R. curvatum. 


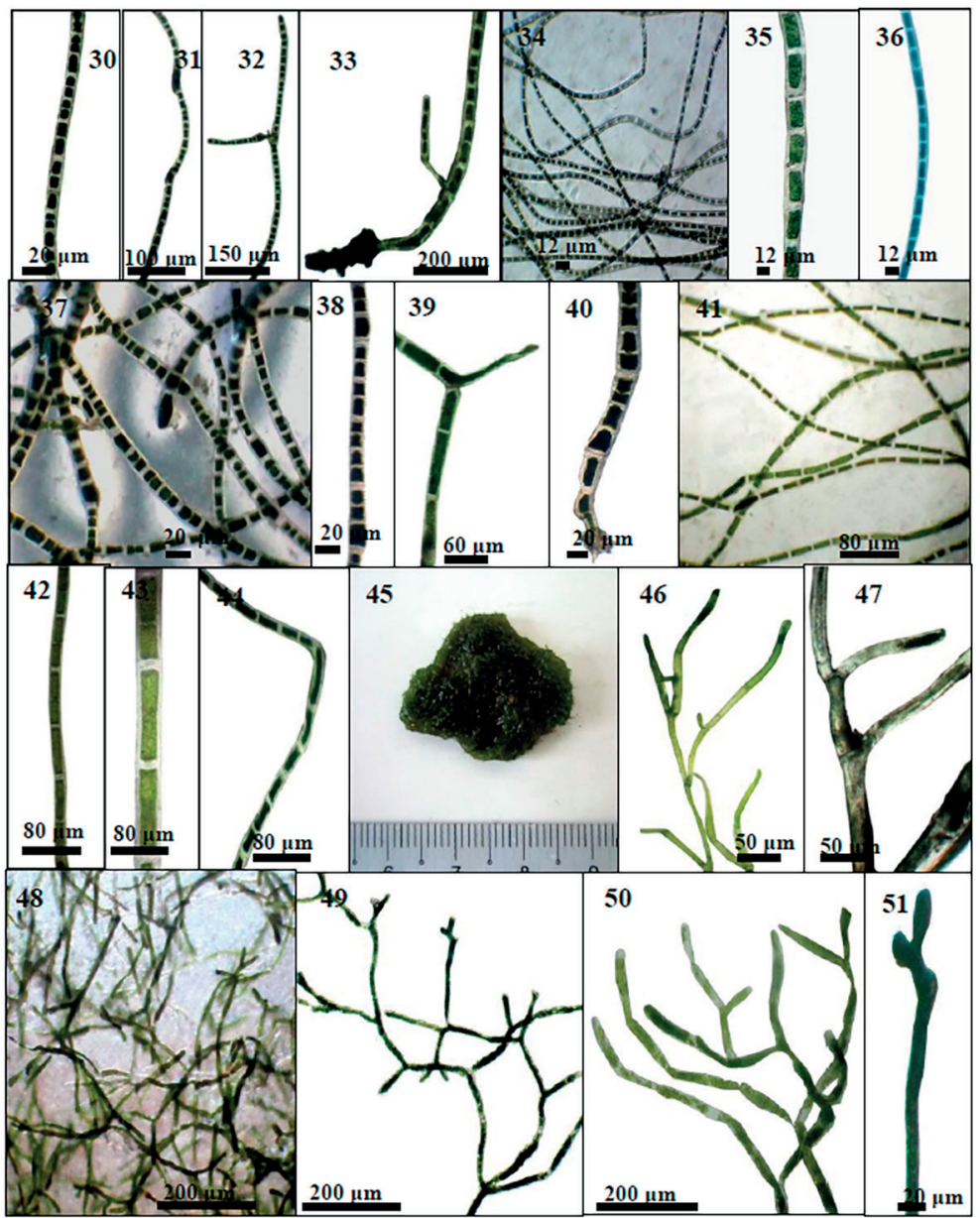

Figs. 3. Cells of R. curvatum; 32) Arcuate filaments of R. curvatum; 33) Apical branchlet of R. curvatum; 34) Lower branchlet of R. curvatum; 35) Habit of Rhizoclonium riparium; 36-37) Cells of R. riparium; 38) Habit of Rhizoclonium grande; 39) Cells of R. grande; and 40) Rhizoidal branchlet of R. grande; 41) Holdfast of Rhizoclonium grande; 42) Habit of R. africanum; 43-44) Cells of R. africanum; 45) Arcuate filament of R. africanum; 46) Habit of Cladophoropsis membranaceae; 47) Branch system of C. membranaceae; 48) Segment of C. membranaceae; 49) Habit of Dichotomosiphon sp; 50-51) Branch system of Dichotomosiphon sp; and 52) Oognium of Dichotomosiphon sp.

\section{Conclusion}

In relation with the present study, it can be considered that marine green algae seem to be the most diverse and abundant species in Apor Seik and there would be other unrecorded seaweed in Kalegauk Island because Kalegauk Island iAfterwardpulation. Aferwards, Kalegauk Island is necessary for the study of other marine algae and the observations of the seasonal ecologyAcknowledgments.

\section{Acknowledgements}

I would like to express my gratitude to $U$ Kyin Aung and Daw Myint Myint San, my dearest parents for financial supports to carry out this study.

\section{References}

1. Womersley, H. B. S. A critical survey of the Marine algae of southern Australia I. Chlorophyta. Australian Journal of Marine and Freshwater Research. 1956. 7(3). pp.343-383.

2. Guiry, M.D. and G.M. Guiry. AlgaeBase. World-wide electronic publication, National University of Ireland, Galway. 2018. http:// www.algaebase.org.
3. Linnaeus, C. Species plantarum. Holmiae [Stockholm], 1753. 2. pp.561-1200.

4. Martens, G.V. List of Algae collected by Mr. S. Kurz in Burma and adjacent Islands. J. Asia. Soc. Bengal. 1871. 40(4). pp.416-469.

5. Anand, P.L. Marine algae from Karachi Part I. Chlorophyceae. The University of the Panjab, Lahore. 1940.

6. Dawson, E.Y. The marine algae of the Gulf of California. Allan Hancock Pacific Expedition. 1944 3(10). pp.189- 454.

7. Kylin, H. Die Chlorophyceae Der Schwedischen Westkuste. Lunds Univ. Arsskrift N. F. Avd. 2. Bd. 1949. 45(4). pp.1-79.

8. Yamada, Y. A list of marine algae from Ryukyusho, Formosa I. Institute of Algological Research, Fac. Of Sci. Hokkaido Univ. 1950. 4(3). pp.173-194.

9. Durairatnam, M. Contribution to the study of the marine algae of Ceylon. Bull. Fish. Res.Stn. 1961. 10. pp.1-181.

10. Soe-Htun, U. The seaweed resources of Myanmar. In: Critchley, A.T. and Ohno, M. (Eds), Seaweed resources of the world. Kanakawa International Fisheries Training Center, Japan International Cooperation Agency (JICA), 1998. pp. 99-105.

11. Soe Pa Pa Kyaw, Mya Kyawt Wai, Thida Nyut, Mu Mu Aye and Soe-Htun, U. Notes on some marine benthic algae of Gwa Coastal Areas: Chlorophyta (Green algae). Journal of Myanmar Academy of Arts and Science. 2009. 7(5). pp.39-86.

12. Soe-Htun, U., Mya Kyawt Wai, Thida Nyunt, Soe Pa Pa Kyaw, Yin Yin Htay, Mu Mu Aye.Checklist, distribution and potential utilization of marine algae of Myanmar I: Chlorophyta (green algae). Journal of Myanmar Academy of Arts and Science. 2009. 7(5). pp.263-277. 
13. Jha, B, Reddy, C.R.K, Thakur, M.C and RaO, M.USeaweeds of India The Diversity and Distribution of seaweed of Gujarat Coast. Developments in Applied Phycology 3.2009. Springer Science+Business Media B.V.

14. Pham, M. N., Tan, H. T. W., Mitrovic, S. and Yeo, H. H. T. A checklist of the algae of Singapore, $2^{\text {nd }}$ Edition. Raffles Museum of Biodiversity Research, National University of Singapore, Singapore. 2011.

15. Arasaki, S. How to know the seaweeds of Japan and its vicinity fully illustrated in colours. Hokuryukan. 1964.

16. Taylor, W. R. Marine algae of the eastern tropical and subtropical coast of the Americas. The University of Michigan Press, $2^{\text {nd }} \mathrm{Re}-$ vised Edition. 1967.

17. Okamura, K. Algae jajonicae exsiccatae. Tokyo. Fasc.Il. Nos. 1903 51-100. [Exsiccata with printed labels].

784 18. Abbott, I.A. and Hollenberg, G.J. Marine algae of California. Stanford University Press, California, U.S.A. 1976.

19. Kyaw Soe, Kyi-Win. 1977. Seaweeds for utilization. University Translation and Publication Department. Publication. 2(168). pp $1-502$.

20.Phang, S. M. Seaweed resources in Malaysia: Current status and future prospects. Aquatic Ecosystem Health \& Mangement. 2006. 9(2). pp.185-202

21. Womersley, H. B. S. The marine benthic flora of Southern Australia. Part I. D.J Woolman, Government Printer, South Australia. 1984.
22. Chapman, V.J. Some new species and forms of marine algae from New Zeland. Farlowia. 1949. 3 pp.495-498.

23. Yoshida, T, Nakajma, Y and Nakata, Y. Checklist of marine algae of Japan. Sorui Jap. J. Phycol. 1985. 33. pp.57-74.

24. Abbott, I.A and Huisman, J.M. Marine green and brown algae of the Hawaiian Islands. Bishop Museum Press. Honolulu, Hawai'i. 2004.

25. Lawson, G.W. and Price, J.H. Seaweeds of the western coast of tropical Africa and adjacent Islands: a critical assessment I. Chlorophyta and Xanthophyta. Bot. J.linn.Soc., 1969. 62. pp.279-346.

26. Egerod, L.E. Analysis of the siphonous Chlorophyta with special reference to the Siphonocladales, Siphonales and Dasycladales of Hawaii. University of California Press. 1952. 25(5). pp.325-454.

27. Tin Aung Moe, Ko., Aung Khin Myint, Ko Chit Aye, U Soe Lwin Research on Myanmar Seaweeds 19: A study on some of the seaweeds found around the Kalagoke Island., Mawlamyine Destrict. 1971. pp 1-32.

Received: 13 november 2018

Accepted: 2 january 2019 